Journal of Business \& Management (COES\&RJ-JBM)

ISSN (E): 2306-7179 ISSN (P): 2306-8043

Publisher: Centre of Excellence for Scientific \& Research Journalism, COES\&RJ LLC

Online Publication Date \& Issue: 1st July 2016, Vol.4, No.3, July 2016

http://centreofexcellence.net/J/JBM/JBM\%20Mainpage.htm

\title{
The Development of Financial Reporting and Auditing Standards throughout the World: Importance of Institutions
}

\author{
Dr. Elene Kharabadze \\ Professor, Head of Accounting and Auditing Department \\ Ivane Javakhishvili Tbilisi State University \\ Ioseb Mamukelashvili, CPA \\ $\mathrm{PhD}$ in Business Administration Candidate \\ Ivane Javakhishvili Tbilisi State University
}

\begin{abstract}
:
We have studied factors that promote the development of financial reporting and auditing standards worldwide and in Georgia. More specifically, similarly to W. Gao's and F. Zhu's approach, we have examined the importance of institutional factors in the development of countries' financial reporting and auditing standards. Our tests indicated that the institutional variables are crucial to the development of the financial reporting and auditing standards. Namely, the most important factor in the development of financial reporting and auditing standards proved to be the protection of minority shareholders' interest, which also played an important role in the development of securities exchanges. Furthermore, we concluded that the soundness of banks was of medium level importance in the development of financial reporting and auditing standards. We have also found that countries' educational system, more specifically the relationship between educational institutions and private sector, were crucial in the above-mentioned development process.
\end{abstract}

Keywords:

Financial reporting, auditing, institutional development, education

\section{Citation:}

Kharabadze, Dr. Elene; Mamukelashvili, Ioseb (2016); The Development of Financial Reporting and Auditing Standards throughout the World: Importance of Institutions; Journal of Business \& Management (COES\&RJ-JBM) Vol.4, No.3, pp.130-139.

This work is licensed under a Creative Commons Attribution 4.0 International License. 
Journal of Business \& Management (COES\&RJ-JBM), 4(2), pp. 130-139

\section{Introduction}

The implementation of financial reporting and auditing standards worldwide has a profound impact on the development countries' financial systems. Therefore, it is crucial to determine factors that hinder the development of financial reporting and auditing standards. Researchers such as Wenlian Gao and Feifei Zhu claim that the quality of financial reporting tends be particularly strong in common law countries, where institutional infrastructure promotes financial transparency, especially during the capital market transactions (Gao \& Zhu, 2013).

According to Gao and Zhu, counties' institutional framework is directly related to the development of financial reporting and auditing standards in these countries. More specifically, they claim that effective legal framework that protects investors interest is crucial in the sense that financial transparency is one of the best ways to protect investors' interests. The implementation of financial reporting and auditing standards enables investors to make more informed decisions regarding capital transactions (Hail \& Leuz, 2006). Considering the fact that Gao and Zhu hypothesize that common law countries have better disclosure and financial reporting practices, it is also no coincidence that capital markets in those countries tend to be more developed than capital markets in civil law countries (Barron \& Qu, 2014).

As a good example that insufficient implementation of financial reporting and auditing standards, Georgia, according to the World Bank, has serious issues with the development of financial reporting and auditing standards. Namely, the WB has claimed that the public availability of financial information is very limited in Georgia and the lack of development of financial reporting profession hinders the development of financial sector of the country (The World Bank, 2015). Furthermore, the World Bank claims that the Georgian stock exchange is dormant and underdeveloped and commercial banks dominate the financial sector.

In addition to examining the impact of legal institutions on the development of financial reporting and auditing standards, we have examined other institutional factors such as soundness of banks and the quality of educational system. Since neither the World Bank nor the OECD claim that the soundness of banks is crucial to the development of financial reporting and auditing standards, we have also examined banks as institutions that potentially promote the implementation of financial reporting and auditing standards. Furthermore, the implementation of financial reporting and auditing standards heavily depends on the quality of education, which led us to consider the quality of scientific research institutions and the cooperation between private sector and universities as part of institutional variables that promote the development of financial reporting and auditing standards (Singer, 2012).

In order to examine the above-mentioned phenomenon, we have analyzed the Global Competitiveness Index of 2014-2015 published by the World Economic Forum. This report ranked 144 countries of the world according to various development characteristics. The ranking systems incorporated 12 co-called pillars ranging from "institutions" to "innovation". We have examined data in the first pillar titled institutions to study the impact of institutional characteristics on the implementation of financial reporting and auditing standards. 


\section{Research Methods}

As mentioned earlier, the source of raw data for our research was the Global Competitiveness Index of 2014-2015. We have picked the following variables from the first pillar of the report titled "institutions": judicial independence, efficiency of legal framework in settling disputes, efficiency of legal framework in challenging regulations, protection of minority shareholders' interests, strength of investor protection and strength of auditing and reporting standards.

All the above-mentioned variables rank the 144 countries of the world from 1 to 7 , where 1 is the worst and 7 is the best mark. Table 1 lists basic descriptive statistics of legal institutional factors for the 144 countries included in our population.

Table 1 - Descriptive Statistics of Legal Institutional Factors Descriptive Statistics

\begin{tabular}{|c|c|c|c|c|c|}
\hline & $N$ & Minimum & Maximum & Mean & $\begin{array}{l}\text { Std. } \\
\text { Deviation }\end{array}$ \\
\hline Judicial independence & 144 & 1.1152 & 6.7496 & 3.871271 & 1.289939 \\
\hline $\begin{array}{l}\text { Efficiency of legal framework } \\
\text { in settling disputes }\end{array}$ & 144 & 1.5453 & 6.1646 & 3.781384 & .9511308 \\
\hline $\begin{array}{l}\text { Efficiency of legal framework } \\
\text { in challenging regs }\end{array}$ & 144 & 1.2192 & 5.5685 & 3.396817 & .8488489 \\
\hline $\begin{array}{l}\text { Strength of auditing and } \\
\text { reporting standards }\end{array}$ & 144 & 2.2041 & 6.7015 & 4.630324 & .9199034 \\
\hline $\begin{array}{l}\text { Protection of minority } \\
\text { shareholders interests }\end{array}$ & 144 & 2.3774 & 6.1733 & 4.144512 & .8142174 \\
\hline $\begin{array}{l}\text { Strength of investor } \\
\text { protection } \\
\text { Valid N (listwise) }\end{array}$ & $\begin{array}{l}144 \\
144\end{array}$ & 1.7000 & 9.7000 & 5.371528 & $\begin{array}{l}1.616508 \\
5\end{array}$ \\
\hline
\end{tabular}

According to Table 1, ranking of 144 countries range from 1 to 7 , where 1 is the worst and 7 is the best mark for all variables except for the strength of investor protection, which ranges from 1 to 10 . Before we conducted parametric statistical tests on above-mentioned data, we ascertained the normality of data distribution using the Kolmogorov-Smirnov and Schapiro-Wilk tests: Table 2 shows the results.

Table 2 - Normality Test Results for Legal Institutions Tests of Normality

\begin{tabular}{|l|l|l|l|l|l|l|}
\hline & \multicolumn{3}{l|l|l|}{ Kolmogorov-Smirnov ${ }^{\mathrm{a}}$} & \multicolumn{2}{l|}{ Shapiro-Wilk } \\
\cline { 2 - 7 } & Statistic & $\mathrm{df}$ & Sig. & Statistic & $\mathrm{df}$ & Sig. \\
\hline $\begin{array}{l}\text { Judicial independence } \\
\text { Efficiency of legal framework } \\
\text { in settling disputes }\end{array}$ & .086 & 144 & .011 & .968 & 144 & .002 \\
$\begin{array}{l}\text { Efficiency of legal framework } \\
\text { in challenging regs } \\
\begin{array}{l}\text { Strength of auditing and } \\
\text { reporting standards }\end{array}\end{array}$ & .090 & 144 & .006 & .972 & 144 & .005 \\
\hline
\end{tabular}


Journal of Business \& Management (COES\&RJ-JBM), 4(2), pp. 130-139

\begin{tabular}{|l|l|l|l|l|l|l|}
$\begin{array}{l}\text { Protection of minority } \\
\text { shareholders interests }\end{array}$ & .051 & 144 & $.200^{*}$ & .986 & 144 & .141 \\
$\begin{array}{l}\text { Strength of investor } \\
\text { protection }\end{array}$ & .083 & 144 & .017 & .987 & 144 & .195 \\
\hline
\end{tabular}

*. This is a lower bound of the true significance.

a. Lilliefors Significance Correction

Table 4 indicates that judicial independence $(\mathrm{SW}=0.968$, $\mathrm{p}=0.002$ ), efficiency of legal framework in settling disputes $(\mathrm{SW}=0.972, \mathrm{p}=0.005)$, efficiency of legal framework in challenging regulations $(\mathrm{SW}=0.978, \mathrm{p}=0.023)$ were not normally distributed because $\mathrm{p}$ value is less than 0.05 , whereas strength of auditing and financial reporting standards $(\mathrm{SW}=0.991, \mathrm{p}=0.510)$, protection of minority shareholders' interests $(\mathrm{SW}=0.986$, $\mathrm{p}=0.141)$ and strength of investor protection $(\mathrm{SW}=0.987, \mathrm{p}=0.195)$ were normally distributed variables because $\mathrm{p}$ value is more than 0.05 . Subsequently, we have used square root transformation technique to normalize the variables that initially were not normally distributed and they were successfully "normalized".

In addition to testing for the normality of distribution, we have ascertained the homogeneity of variances before we conducted parametric statistical tests on data. Graph 1 shows the graphical representation of the homogeneity of variances for the abovementioned variables and it satisfies our requirements.

Graph 1 - Homogeneity of Variances for Legal Institutions

Correlations

\begin{tabular}{|c|c|c|c|c|c|c|c|}
\hline & & $\begin{array}{l}\text { Judicial } \\
\text { indepe } \\
\text { ndence }\end{array}$ & \begin{tabular}{|l|} 
Efficienc \\
$y \quad$ of \\
legal \\
framewo \\
rk in \\
settling \\
disputes
\end{tabular} & $\begin{array}{l}\text { Efficienc } \\
y \quad \text { of } \\
\text { legal } \\
\text { framew } \\
\text { ork in } \\
\text { challeng } \\
\text { ing regs }\end{array}$ & $\begin{array}{l}\text { Strength } \\
\text { of } \\
\text { auditing } \\
\text { and } \\
\text { reportin } \\
\text { g } \\
\text { standar } \\
\text { ds }\end{array}$ & \begin{tabular}{|l|} 
Protect \\
ion of \\
minorit \\
$y$ \\
shareh \\
olders \\
interest \\
s
\end{tabular} & $\begin{array}{l}\text { Strength of investor } \\
\text { protection }\end{array}$ \\
\hline $\begin{array}{l}\text { Judicial } \\
\text { independence }\end{array}$ & $\begin{array}{l}\text { Pearson } \\
\text { Correlation } \\
\text { Sig. } \\
\text { tailed) } \\
\mathrm{N} \\
\end{array}$ & 144 & $\begin{array}{l}.867^{* *} \\
.000 \\
144 \\
\end{array}$ & $\begin{array}{l}.867^{* *} \\
.000 \\
144 \\
\end{array}$ & $\begin{array}{l}.742^{* *} \\
.000 \\
144 \\
\end{array}$ & $\begin{array}{l}.799^{* *} \\
.000 \\
144\end{array}$ & $\begin{array}{l}.365^{* *} \\
.000 \\
144\end{array}$ \\
\hline $\begin{array}{ll}\text { Efficiency } & \text { of } \\
\text { legal } & \\
\text { framework } & \text { in } \\
\text { settling } & \\
\text { disputes } & \\
\end{array}$ & $\begin{array}{l}\text { Pearson } \\
\text { Correlation } \\
\text { Sig. } \\
\text { tailed) } \\
\mathrm{N}\end{array}$ & $\begin{array}{l}.867^{* *} \\
.000 \\
144 \\
\end{array}$ & 144 & $\begin{array}{l}.928^{\star *} \\
.000 \\
144 \\
\end{array}$ & $\begin{array}{l}.767^{* *} \\
.000 \\
144 \\
\end{array}$ & $\begin{array}{l}.873^{* *} \\
.000 \\
144 \\
\end{array}$ & $\begin{array}{l}.399^{* *} \\
.000 \\
144 \\
\end{array}$ \\
\hline $\begin{array}{l}\text { Efficiency of } \\
\text { legal }\end{array}$ & $\begin{array}{l}\text { Pearson } \\
\text { Correlation }\end{array}$ & $.867^{* \star}$ & $.928^{* *}$ & 1 & $.741^{* *}$ & $.843^{* *}$ & $.385^{* *}$ \\
\hline
\end{tabular}


The Development of Financial Reporting and Auditing Standards....

\begin{tabular}{|c|c|c|c|c|c|c|c|}
\hline $\begin{array}{l}\text { framework in } \\
\text { challenging } \\
\text { regs }\end{array}$ & $\begin{array}{ll}\text { Sig. } & (2- \\
\text { tailed }) & \\
N & \end{array}$ & $\begin{array}{l}.000 \\
144\end{array}$ & $\begin{array}{l}.000 \\
144\end{array}$ & 144 & $\begin{array}{l}.000 \\
144\end{array}$ & $\begin{array}{l}.000 \\
144\end{array}$ & $\begin{array}{l}.000 \\
144\end{array}$ \\
\hline $\begin{array}{lr}\text { Strength } & \text { of } \\
\text { auditing } & \text { and } \\
\text { reporting } & \\
\text { standards } & \end{array}$ & $\begin{array}{l}\text { Pearson } \\
\text { Correlation } \\
\text { Sig. } \\
\text { tailed) } \\
\mathrm{N}\end{array}$ & $\begin{array}{l}.742^{* *} \\
.000 \\
144\end{array}$ & $\begin{array}{l}.767^{* *} \\
.000 \\
144\end{array}$ & $\begin{array}{l}.741^{* *} \\
.000 \\
144\end{array}$ & 144 & $\begin{array}{l}.914^{* *} \\
.000 \\
144\end{array}$ & $\begin{array}{l}.436^{* *} \\
.000 \\
144\end{array}$ \\
\hline $\begin{array}{l}\text { Protection of } \\
\text { minority } \\
\text { shareholders } \\
\text { interests }\end{array}$ & $\begin{array}{l}\text { Pearson } \\
\text { Correlation } \\
\text { Sig. } \\
\text { tailed) } \\
\mathrm{N} \\
\end{array}$ & $\begin{array}{l}.799^{\star *} \\
.000 \\
144 \\
\end{array}$ & $\begin{array}{l}.873^{* *} \\
.000 \\
144 \\
\end{array}$ & $\begin{array}{l}.843^{* *} \\
.000 \\
144 \\
\end{array}$ & $\begin{array}{l}.914^{* *} \\
.000 \\
144 \\
\end{array}$ & 144 & $\begin{array}{l}.443^{* *} \\
.000 \\
144 \\
\end{array}$ \\
\hline $\begin{array}{l}\text { Strength of } \\
\text { investor } \\
\text { protection }\end{array}$ & $\begin{array}{l}\text { Pearson } \\
\text { Correlation } \\
\text { Sig. } \\
\text { tailed) } \\
\mathrm{N}\end{array}$ & $\begin{array}{l}.365^{\star *} \\
.000 \\
144\end{array}$ & $\begin{array}{l}.399^{* *} \\
.000 \\
144\end{array}$ & $\begin{array}{l}.385^{* *} \\
.000 \\
144\end{array}$ & $\begin{array}{l}.436^{\star *} \\
.000 \\
144\end{array}$ & $\begin{array}{l}.443^{* *} \\
.000 \\
144\end{array}$ & 144 \\
\hline
\end{tabular}

**. Correlation is significant at the 0.01 level (2-tailed).

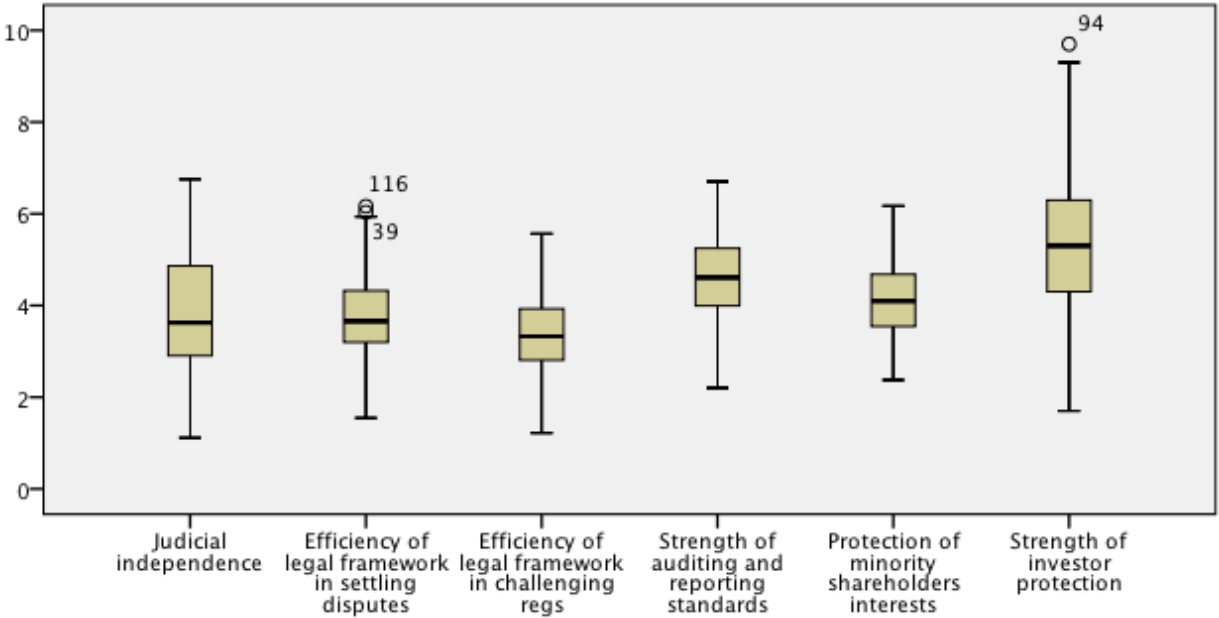

We have examined the relationship between the legal institutional factors - judicial independence, efficiency of legal framework in settling disputes, efficiency of legal framework in challenging regulations, protection of minority shareholders' interests, strength of investor protection - with the strength of auditing and reporting standards. Our tests included both the correlation and regression analyses, in that order.

Table 3 shows the result of correlation between the above-mentioned variables. Notably, all of the correlation coefficients are statistically significant due to the fact that $\mathrm{p}=0.000$. The correlation between the strength of auditing and financial reporting standards and legal institutional variables were as follows: judicial independence - 0.742 , efficiency of legal framework in settling disputes -0.767 , Efficiency of legal framework in challenging regulations -0.741 , Protection of minority shareholders' interests -0.914 and strength of investor protection -0.436 . Although all of the correlation coefficients were relatively strong (except for the correlation between the strength of auditing and financial reporting 
standards, which is 0.436), the correlation is strongest between the strength of auditing and financial reporting standards and protection of minority shareholders' interest. This tendency is very logical in the sense that minority shareholders are more vulnerable to informational asymmetry problems than majority shareholders that have more control over the company's management (this is especially true for capital market transactions).

Table 3 - Correlation Coefficients between the Strength of Auditing and Financial Reporting Standards and Legal Institutional Factors

We can infer from the correlation coefficients above that the implementation of auditing and financial reporting standards depend on legal institutional factors. However, correlation does not illustrate cause and effect relationship, thus the connection between legal institutional factors and the strength of auditing and financial reporting standards could be a coincidence. In other words, effective legal institutions might not necessarily cause implementation of auditing and financial reporting standards.

In order to examine cause and effect relationship between the legal institutional factors and auditing and financial reporting standards, we have conducted regression analyses, where the legal institutional factors were independent variables and the strength of auditing and financial reporting standards was a dependent variable.

Table 4 portrays the result of regression analyses, where the strength of auditing and financial reporting standards was a dependent variable and legal institutional variables individually - independent variables. In this instance, we received medium-level regression result for judicial independence (0.547), Efficiency of legal framework in settling disputes (0.585) and Efficiency of legal framework in challenging regulations (0.546). The regression result for the strength of investor protection as the independent variable was a relatively weak 0.185 (as it was for correlation).

Table 4 - Regression Analyses: Legal Institutional Factors and Auditing and Financial Reporting Standards

\begin{tabular}{|l|l|l|l|l|}
\hline Variable Name & $\mathbf{R}$ & $\begin{array}{l}\mathbf{R} \\
\text { Square }\end{array}$ & $\begin{array}{l}\text { Adjusted } \\
\mathbf{R} \\
\text { Square }\end{array}$ & $\begin{array}{l}\text { Std. Error of the } \\
\text { Estimate }\end{array}$ \\
\hline Judicial independence & 0.742 & 0.55 & 0.547 & 0.6193503 \\
\hline $\begin{array}{l}\text { Efficiency of legal framework } \\
\text { in settling disputes }\end{array}$ & 0.767 & 0.588 & 0.585 & 0.5927622 \\
\hline $\begin{array}{l}\text { Efficiency of legal framework } \\
\text { in challenging regulations }\end{array}$ & 0.741 & 0.549 & 0.546 & 0.6201096 \\
\hline $\begin{array}{l}\text { Protection of minority } \\
\text { shareholders interests }\end{array}$ & 0.914 & 0.835 & 0.834 & 0.374929 \\
\hline Strength of investor protection & 0.436 & 0.19 & 0.185 & 0.8306482 \\
\hline
\end{tabular}

The strongest regression result was the relationship between the protection of minority shareholders' interests and the strength of auditing and financial reporting standards, 0.834. In other words, the protection of minority shareholders' interests from a legal point of view is the biggest precondition for the implementation of auditing and financial reporting standards. Graph 2 illustrates the strength of the regression result, where the protection of minority shareholders' interests was a predictor. 
Graph 2 - Graphical Illustration of the Regression Result: Protection of Minority Shareholders' Interests

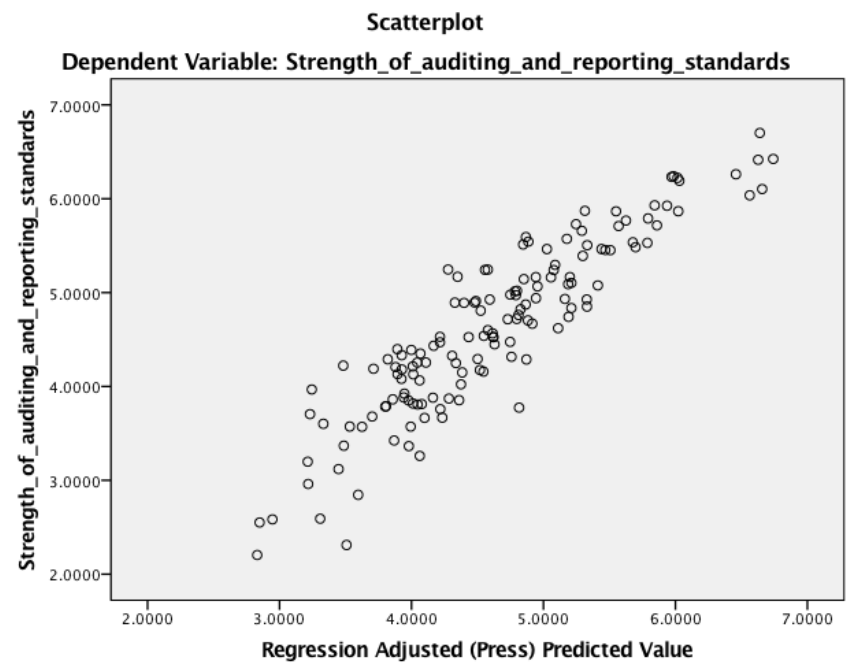

Once we have ascertained that legal institutional framework is essential to the implementation of auditing and financial reporting standards, we have tested the hypothesis that soundness of banks affects the implementation of auditing and financial reporting standards. The "soundness of banks" variable comes from the Global Competitiveness Index's $8^{\text {th }}$ pillar, titled financial market development. In addition, we have tested the assumption that high quality educational and research institutions improve the implementation of auditing and financial reporting standards. For that purpose, we have selected "quality of scientific research institutions" and "university-industry collaboration in research and development" as our research variables that belong to the Global Competitiveness Index's $12^{\text {th }}$ pillar titled "innovation". As we have done earlier, we have tested the new variables for normality of data distribution and we have ascertained that their variances are homogeneous. Subsequently, we have conducted correlation and regression analyses, just as we have done for legal institutional variables.

Table 5 shows the result of correlation analyses between the strength of auditing and reporting standards and the following variables: soundness of banks (0.736), quality of scientific research institutions (0.749) and university industry collaboration in research and development (0.776).

Table 5 - Correlation between Soundness of Banks, Educational Variables and Auditing and Financial Reporting Standards

\section{Correlations}

\begin{tabular}{|c|c|c|c|c|}
\hline & $\begin{array}{l}\text { Soundness } \\
\text { of banks }\end{array}$ & $\begin{array}{l}\text { Quality of } \\
\text { scientific } \\
\text { research } \\
\text { institutions }\end{array}$ & $\begin{array}{l}\text { University } \\
\text { industry } \\
\text { collaborati } \\
\text { on in RD }\end{array}$ & $\begin{array}{l}\text { Strength of } \\
\text { auditing } \\
\text { and } \\
\text { reporting } \\
\text { standards }\end{array}$ \\
\hline $\begin{array}{ll}\begin{array}{l}\text { Soundness of } \\
\text { banks }\end{array} & \text { Coarson } \\
& \text { Sig. (2-tailed) }\end{array}$ & 1 & $\begin{array}{l}.424^{* *} \\
.000\end{array}$ & $\begin{array}{l}.496^{* *} \\
.000\end{array}$ & $\begin{array}{l}.736^{* *} \\
.000\end{array}$ \\
\hline
\end{tabular}


Journal of Business \& Management (COES\&RJ-JBM), 4(2), pp. 130-139

\begin{tabular}{|c|c|c|c|c|c|}
\hline & $\mathrm{N}$ & 144 & $\mid 144$ & 144 & 144 \\
\hline $\begin{array}{ll}\text { Quality } & \text { of } \\
\text { scientific } & \\
\text { research } & \\
\text { institutions } & \end{array}$ & $\begin{array}{l}\text { Pearson } \\
\text { Correlation } \\
\text { Sig. (2-tailed) } \\
\mathrm{N}\end{array}$ & $\begin{array}{l}.424^{* *} \\
.000 \\
144\end{array}$ & $\begin{array}{l}1 \\
144\end{array}$ & $\begin{array}{l}.951^{* *} \\
.000 \\
144\end{array}$ & $\begin{array}{l}.749^{* \star} \\
.000 \\
144\end{array}$ \\
\hline $\begin{array}{l}\text { University } \\
\text { industry } \\
\text { collaboration } \\
\text { in RD }\end{array}$ & $\begin{array}{l}\text { Pearson } \\
\text { Correlation } \\
\text { Sig. (2-tailed) } \\
\mathrm{N}\end{array}$ & $\begin{array}{l}.496^{* *} \\
.000 \\
144 \\
\end{array}$ & $\begin{array}{l}.951^{* *} \\
.000 \\
144 \\
\end{array}$ & $\begin{array}{l}1 \\
144 \\
\end{array}$ & $\begin{array}{l}.776^{\star *} \\
.000 \\
144 \\
\end{array}$ \\
\hline $\begin{array}{lr}\text { Strength } & \text { of } \\
\text { auditing and } \\
\text { reporting } \\
\text { standards }\end{array}$ & $\begin{array}{l}\text { Pearson } \\
\text { Correlation } \\
\text { Sig. (2-tailed) } \\
\mathrm{N}\end{array}$ & $\begin{array}{l}.736^{* *} \\
.000 \\
144\end{array}$ & $\begin{array}{l}.749^{* *} \\
.000 \\
144\end{array}$ & $\begin{array}{l}.776^{\star *} \\
.000 \\
144\end{array}$ & 144 \\
\hline
\end{tabular}

${ }^{\star *}$. Correlation is significant at the 0.01 level (2-tailed).

Although correlation coefficients between the strength of auditing and financial reporting standards and soundness of banks as well as educational institutions are higher than average, we conducted regression analyses to study cause and effect relationships between the above-mentioned variables. Table 6 illustrates the result of regression analyses, where soundness of banks and educational institutions were independent variables and the strength of auditing and reporting standards - dependent variable.

Table 6 - Regression Analyses: Soundness of Banks, Education Institutional Factors

\begin{tabular}{|l|l|l|l|l|}
\hline Variable Name & $\mathbf{R}$ & $\begin{array}{l}\mathbf{R} \\
\text { Squar } \\
\mathbf{e}\end{array}$ & $\begin{array}{l}\text { Adjusted } \\
\mathbf{R} \\
\text { Square }\end{array}$ & $\begin{array}{l}\text { Std. Error of the } \\
\text { Estimate }\end{array}$ \\
\hline Soundness of banks & $\begin{array}{l}0.73 \\
6\end{array}$ & 0.542 & 0.539 & 0.6248861 \\
\hline $\begin{array}{l}\text { Quality of scientific research } \\
\text { institutions }\end{array}$ & $\begin{array}{l}0.74 \\
9\end{array}$ & 0.561 & 0.558 & 0.6114946 \\
\hline $\begin{array}{l}\text { University-industry collaboration in } \\
\text { R\&D }\end{array}$ & $\begin{array}{l}0.77 \\
6\end{array}$ & 0.603 & 0.6 & 0.5819607 \\
\hline
\end{tabular}

As Table 6 indicates, regression analyses show moderately strong connection between the strength of auditing and financial reporting standards and soundness of banks -0.539 and quality of scientific research institutions -0.558 . The highest regression coefficient exists for the university-industry collaboration in research and development as an independent variable -0.6 .

\section{Conclusion}

The null hypothesis $\mathrm{H}_{0}$ of our research was that institutional framework, illustrated by legal, banking and educational factors, does not influence the implementation of auditing and financial reporting standards. Regression analyses confirmed the alternative hypothesis in the following way: we were able to infer that legal institutions, soundness of banks, quality of scientific research institutions and university-industry collaboration in research have significant influence on the implementation of audit and financial reporting standards. 
The Development of Financial Reporting and Auditing Standards....

We have further illustrated that the most important institutional mechanism to ensure the implementation of auditing and financial reporting standards is the protection of minority shareholders' interests, which is evidenced by 0.834 regression coefficient, where the protection of minority shareholders' interests was an independent variable and the strength of auditing and financial reporting standards - a dependent variable.

Consistent with our expectations, soundness of banks possesses medium-level influence on the implementation of auditing and financial reporting standards, evidenced by the regression coefficient of 0.539 . On the other hand, we have determined that universityindustry collaboration has medium to high importance on the implementation process of auditing and financial reporting standards with a regression coefficient of 0.6.

\section{References}

Öztekin, Ö. (2015). Capital Structure Decisions around the World: Which Factors Are Reliably Important? Journal of Financial \& Quantitative Analysis, 301-323.

Barron, O., \& Qu, H. (2014). Information Asymmetry and the Ex Ante Impact of Public Disclosure Quality on Price Efficiency and the Cost of Capital: Evidence from a Laboratory Market. Accounting Review, 1269-1297.

Bruhn, M., \& Love, I. (2014). The Real Impact of Improved Access to Finance: Evidence from Mexico. Journal of Finance, 1347-1376.

Cattaneo, M., Meoli, M., \& Vismara, S. (2015). Financial regulation and IPOs: Evidence from the history of the Italian stock market. Journal of Corporate Finance, 116132.

Committee on Banking, Housing, and Urban Affairs. Subcommittee on Securities, Insurance, and Investment. (2009). Over-the-counter derivatives : modernizing oversight to increase transparency and reduce risks. United States Congress, 1172.

DeFond, M., Hu, X., Hung, M., \& Li, S. (2011). The Impact of Mandatory IFRS Adoption on Foreign Mutual Fund Ownership: The Role of Comparability. Journal of Accounting and Economics, 240-258.

Dong, Y., \& Men, C. (2014). SME Financing in Emerging Markets: Firm Characteristics, Banking Structure and Institutions. Emerging Markets Finance \& Trade, 120-149.

Fu, R., Kraft, A. G., \& Zhang, H. (2012). Financial Reporting Frequency, Information Asymmetry, and the Cost of Equity. Journal of Accounting \& Economics, 132149.

Gao, W., \& Zhu, F. (2013). Information asymmetry and capital structure around the world. Pacific-Basin Finance Journal, 1-42.

Granja, J. (2013). Disclosure Regulation in the Commercial Banking Industry: Lessons from the National Banking Era. Chicago: University of Chicago.

Hail, L., \& Leuz, C. (2006). International Differences in the Cost of Equity Capital: Do Legal Institutions and Securities Regulation Matter? Journal of Accounting Research, 1-44.

Kim, J.-B., Shi, H., \& Zhou, J. (2014). International Financial Reporting Standards, institutional infrastructures, and implied cost of equity capital around the world. Review of Quantitative Finance \& Accounting, 469-507. 
Journal of Business \& Management (COES\&RJ-JBM), 4(2), pp. 130-139

Manyara, S. M., \& Benuto, L. (2014). Adoption of International Financial Reporting Standards Improves Access to Equity Capital in Australia. Academy of Accounting and Financial Studies Journal, 51-67.

Mody, A., \& Taylor, M. P. (2013). International capital crunches: the time-varying role of informational asymmetries. Applied Economics, 2961-2973.

Myers, S. C., \& Majluf, N. S. (1984). Corporate Financing and Investment Decisions When Firms Have Information that Investors Do Not Have. Journal of Financial Economics, 187-221.

Naranjo, P., Saavedra, D., \& Verdi, R. S. (2014). Financial Reporting Regulation and Financing Decisions. Working Paper, 1-56.

OECD. (2011). Competitiveness and Private Sector Development: Eastern Europe and South Caucasus.

Orin, R. M. (2008). Ethical Guidance and Constraint Under the Sarbanes-Oxley Act of 2002. Journal of Accounting, Auditing \& Finance.

Schwab, K. (2014). The Global Competitiveness Report 2014-2015. World Economic Forum, 1-565.

Seifert, B., \& Gonenc, H. (2010). Pecking Order Behavior in Emerging Markets. Journal of International Financial Management \& Accounting, 1-31.

Singer, R. A. (2012). How to Integrate International Financial Reporting Standards into Accounting Programs. American Journal of Business Education.

The European Parliament. (1978). Fourth Council Directive 78/660/EEC.

The Parliament of Georgia. (1999). The Law on Securities Market.

The World Bank. (2015). Georgia: Accounting and Auditing. Report on the Observance of Standards and Codes (ROSC), 1-66. 